\title{
Tulevaisuusdialogi ja dialogin tulevaisuus
}

ROBERT ARNKIL

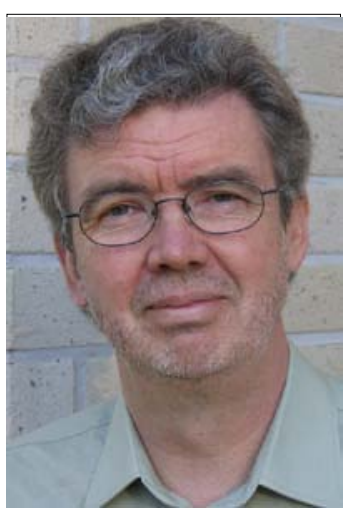

Olen yhdessä Stakesin verkostotiimin - ja siellä erityisesti Tom Arnkilin ja Esa Eriksonin, sekä kollegani Timo Spagarin (Spangar Negotiations) kanssa kehitellyt ja toteuttanut useiden vuosien aikana dialogisia menetelmiä erilaisissa yhteyksissä, vaihdellen asiakastyöstä työorganisaatioiden ja verkostojen kehittämiseen. Eräs näistä dialogisista menetelmistä on ollut tulevaisuusdialogi, jota käsittelen tässä artikkelissa.
Tulevaisuusdialogi kuuluu dialogisten menetelmien laajempaan "perheeseen" ja vielä yleisemmältä kannalta katsoen ennen kaikkea konstruktionistisiin, narratiivisiin ja diskurssianalyyttisiin menetelmiin (Shotter 1993). Tulevaisuusdialogi on interventio ryhmään, organisaatioon ja/tai verkostoon ja liittyy tätä kautta toimintatutkimukselliseen traditioon (Denzin ja Lincoln 2000). Tulevaisuusdialogiin liittyy kuitenkin vielä paljon sekä teoreettisia että käytännöllisiä haasteita, joita tässä pyrin tunnistamaan

Dialogisuudesta puhutaan tänä päivänä paljon ja sitä kohtaan tunnetaan työelämässä kiinnostusta. Dialogisuudelle ei kuitenkaan ole olemassa mitään yhtä määritelmää. Useimmiten sillä tarkoitetaan sellaista inmisten välistä vuoropuhelua, jota luonnehtii yhdessä etsiminen, toisen kuunteleminen, kiinnostus toisen näkemyksiä kohtaan ja keskinäinen luottamus. Hyvä analogia on ystävien välinen keskustelu, johon he uppoutuvat.

"Dialogi ei ole vain puhumista, se ei ole keskustelua, se ei ole väittelyä, debattia. Dialogilla on toisenlainen luonne. Dialogi on ... yritys ymmärtää toisiaan. Ei yrittäen väitellä, ei yrittäen keskustella - ainoastaan myötätuntoinen asenne. Dialogi on osallistumista toi- sen olemiseen: kaksi ystävää... puhumassailman vastakkainasettelua, ilman yritystä todistaa olevansa itse oikeassa ja toinen väärässä....

...Ensimmäinen asia mikä pitää ymmärtää, on että vain ystävät voivat keskustella elämästä. Kun keskustelusta tulee vastakkainasettelua, kun siitä tulee debatti, dialogi särkyy. Elämästä ei voi keskustella sillä tavoin. Vain ystävät voivat, koska silloin keskustelu ei ole väittely, se on dialogi"

(Osho, siteerannut Roman 2005)

Dialogista ja dialogisuudesta on myös toisenlaisia käsityksiä, mutta kaikissa korostetaan se erityisyyttä vuoropuheluun sitoutumisen, vastavuoroisuuden, kuuntelemisen ja yhteisen oivalluksen ja elämyksen mielessä (Bohm 1996, Isaacs 1999, Bahtin 2002, Burbules 1993). Hyväksykäämme toistaiseksi ajatus siitä, että dialogi on olemukseltaan ystävien keskustelua.

Mutta miksi tällaista "ystävien keskustelua" sitten nyt erityisesti kaivataan? Mistä dialogisuusbuumi?

Dialogisten menetelmien "gurut" liittävät dialogisuuden tarpeen ennen kaikkea yhteiskunnan monimutkaistumiseen ja hajoamiseen, fragmentoitumiseen, jonka seurauksena syntyy tarve ylit- 
tää rajoja, rakentaa siltoja, eheyttää, saada kokonaiskuva, toimia yhdessä (Bohm, Isaacs, ibid.). Teollisuusyhteiskunta, tai ensimmäinen moderni - miksi sitä haluammekaan nimittää (Beck 2000) - loi alati haarautuvan työnjaon ja hierarkiat. Nyt elämme keskellä jälkiteollista, toista modernia tai tietoyhteiskuntaa, jossa yllättävien, moniulotteisten ja nopeiden muutosten keskellä verkostoidutaan. "Ystävät" yrittävät siis selviytyä monimutkaisista haasteista yhteistyöllä, yhdistämällä voimiaan. Yhdistämisessä auttaa dialogi.

Eräs kiinnostavimmista kokemuksista on ollut tulevaisuusdialogin toteuttaminen. Tyypillinen toteutustilanne on useista eri toimijoista koostuva työpaja tai konferenssi, jossa käsitellään jotain ongelmaa, joka vaatii useiden tahojen yhteistyötä ja on luonteeltaan monimutkainen ja moniselitteinen. Tulevaisuusdialogi toteutetaan niin, että osanottajia pyydetään kuvittelemaan, että jollain "ihmeenomaisella" tavalla siirrytään ajassa eteenpäin, esimerkiksi vuosi tai kaksi (riippuen käsillä olevan asian luonteesta) ja käsillä olevassa asiassa on tapahtunut merkittävää edistystä. Tämän jälkeen tapahtuman vetäjä, ulkopuolinen taho, käynnistää dialogin, jossa osanottajien tehtävänä on kertoa, mitä on tapahtunut. He siis muistelevat (hyvää) tulevaisuutta.

Miksi (hyvää) tulevaisuutta? Kysymys on epävarman, monimutkaisen ja auki olevan tulevaisuuden tutkimisesta yhdessä. Ei tulevaisuuden ennustamisen mielessä, vaan toisten ja omiin käsityksiin tutustumisen mielessä - ja samalla yhteisten toimintamahdollisuuksien oivaltamisen mielessä.

\section{Tarina Tampereelta}

Antakaamme ensin esimerkin puhua. Käytän esimerkkinä 2002-2004 Tampereen seudulla toteutettuja dialogisia työkonferensseja, jotka toteutettiin (pääosin) tulevaisuusdialogimenetelmällä. Keskityn erityisesti niistä ensimmäiseen ja tämän esimerkin kautta kehkeytän esiin tulevaisuusdialogin keskeiset ideat ja menetelmät. Lopuksi pohdin tulevaisuusdialogin teoreettisia ja käytännöllisiä yhteyksiä sekä tulevaisuuden haasteita.

Tampereen tarina kuuluu seuraavasti:

Tampereen seudulla on usean vuoden aikana kehitetty yhteistyötä eri tahojen kesken työllisyyden edistämiseksi ja työttömyyden ja syrjäytymi- sen torjumiseksi, mikä on vaativa ja moniulotteinen aihe. Näissä merkeissä järjestetään laaja työpaja marraskuussa 2002. Tapahtumapaikkana on Tampereen valtuustosali. Noin sata ihmistä on salissa, edustaen julkisia palveluja, niin paikallisesti, kuin valtion keskushallinnon tasolta, yrityksiä, vapaaehtoistoimintaa, työllisyysprojekteja, onpa joukossa ihan oikeita työttömiäkin. Minut on pestattu toimimaan päivän vetäjänä. Menetelmänä on tulevaisuusdialogi. Jututan vuorollaan salin edessä edellä mainittujen "äänien" edustajia, pienenä ryhmänä, muiden kuunnellessa. Teemme aikamatkan tulevaisuuteen, emme olekaan marraskuussa 2002, vaan marraskuussa 2004. IImoitan, että olemme "oikeasti" tulevaisuudessa. Siirrymme sinne "ihmeenomaisesti". Kukin kertoo omalta kannaltaan, mikä kuluneessa kahdessa vuodessa on erityisesti ilahduttanut työllisyyden edistämistä koskevan yhteistyön kehityksessä. Kysyn heiltä mitä he ovat itse tehneet ja kenen kanssa. Kysyn myös olivatko he huolissaan jostakin työllisyyttä koskevan yhteistyön kehityksestä "kun tapasimme silloin kaksi vuotta sitten" (siis itse asiassa tänään...) ja mikä sai tuon huolen vähenemään.

Yrittäjät, esimerkiksi, kertovat siis omalta kannaltaan, mahdollisimman konkreettisesti, mikä heitä on ilahduttanut ja millaisessa toiminnassa he ovat olleet mukana, kenen kanssa erityisesti ja mikä heitä on yrittäjänä huolestuttanut. He siis kertovat eräänlaisen "tulevaisuustarinan" siitä, mikä on ollut heille tärkeää. Sitten kuullaan toista "ääntä", jne. Välillä puheenvuoro avataan kuuntelevalle yleisölle, edelleen tulevaisuudessa pysyen, muistavatko he vielä jotain itse kutakin ilahduttanutta asiaa, huolia, jne.

Päivä etenee hyvin, ihmiset eläytyvät tulevaisuuteen, ovat siitä vähän yllättyneitä, huvittuneitakin. Välillä, kun joku ponnistelee "tulevaisuuden muistamisen" kanssa, kuuluu hyväntahtoista nauruakin. Keskustelijat peesaavat toistensa juttuja, jatkavat tarinoita, keksivät lisää. Ovat huvittuneita ja yllättyneitä toisten heille löytämistä tulevaisuusrooleista ja omista lupauksistaan.. Tunnelma lämpenee. Sitten, eräässä vaiheessa kun annan puheenvuoron taas yleisölle, yllättäen ylös nousee mies noin viisissäkymmenissä ja toteaa: "Täällä on puhuttu paljon siitä, mitä hyviä asioita on tapahtunut tässä kahden vuoden aikana. Mutta kun olin täällä viimeksi kaksi vuotta sitten, olin ollut kaksi vuotta työttömänä ja nyt olen edelleen ollut kaksi vuot- 
ta työttömänä." Ja mies istuu alas. Sali hiljenee. Minun pääni hiljenee myös. Ja juuri kun kaikki oli menossa niin hyvin... Mietin mitä pitäisi tehdä. Olen hetken ymmälläni, mutta päätän vain odottaa. Hetken päästä miehen takaa nousee yllättäen toinen mies, joka sanoo: "Mutta Jussi, nyt sinä muistat väärin, silloin kaksi vuotta sittenhän minä tarjosin sinulle työpaikan...ja nyt sinä olet ollut meillä töissä nämä kaksi vuotta!" Kuuluu hämmentynyttä kohinaa ja naurua salissa. Tunnelma lähtee taas lämpenemään. Ja työtarjous on aito.

Vuoden (2003) ja kahden vuoden (2004) pääs- tä järjestettiin vastaavat dialogit, joissa tarkasteltiin "oikeata tulevaisuutta", eli missä määrin kuviteltu tulevaisuus on toteutunut ja kuviteltiin taas eteenpäin.

\section{Tulevaisuusdialogin ulottuvuudet, teemat ja menetelmät}

Tulevaisuusdialogi on siten rikas ja yllättäväkin tapahtuma. Sen kuuleminen tarinana on siinä mielessä hyvä, että lukija pystyy todennäköisesti, ainakin jossain määrin, kuvittelemaan tapah-

Kuvio 1: Tulevaisuusdialogin tapahtumat, teemat ja ulottuvuudet

\section{Tapahtuma}

Tampereen seudulla...yhteistyötä työllisyyden edistämiseksi...vaativa ja moniulotteinen aihe ...tapahtumapaikkana...

... eri tahojen yhteistyönä Tampereen seudulla... ...monena vuonna toteutettu...

...useita hankkeita...

...edustaen niin paikallisesti kuin... keskushallinnon tasolta...

...joukossa ihan oikeita työttömiäkin...

... päivän vetäjä...

...menetelmänä tulevaisuusdialogi...

....äänet"...

...muiden kuunnellessa...

...kukin kertoo mikä on ilahduttanut...

...mitä itse tehneet...

...kenenkanssa...

...olivatko he huolissaan...ja mikä sai huolen vähenemään

...ovat yllättyneitä, huvittuneitakin...naurua.. jatkavat tarinoita, keksivät lisää...ovat yllättyneitä.. toisten heille löytämistä tulevaisuusrooleista...ja omista lupauksistaan

...kertovat eräänlaisen "tulevaisuustarinan"... ...YYllättäen nousee mies..."olen edelleen työttömänä" ...YYllättäen nousee toinen mies ..."sinähän olet ollut töissä..."

...Olen ymmälläni... mutta päätän odottaa ...uudet dialogit...vuoden ja kahden päästä...

\section{Aiheet, teemat, menetelmät}

Dialogisen tapahtuman aihe on moniulotteinen, kompleksinen

"Tila", "areena", jossa dialogi tapahtuu

Ratkaisuja yritetään monitoimijaisesti

Ratkaisuja on yritetty aikaisemminkin, aika Hankkeita on ollut ja on, useita, "projektoituminen"

Paikalla on useita eri tahoja ja tasoja...

...mukaan lukien kansalaiset

Tapahtuman rakenteeseen kuuluu fasilitaattori Dialogisuutta edistetään...

...artikuloimalla näkökulmia

...erottamalla puhuminen ja kuunteleminen

...korostamalla hyvää tulevaisuutta ja ratkaisukeskeisyyttä

...kunkin osanottajan omaa panosta

...verkostoyhteistyötä

...ottamalla huomioon myös huolenaiheet ja esteet

...luomalla luova ilmapiiri ja keskustelutapa

...käyttämällä tarinoita, jotka resonoivat... ...tilanteeseen kuuluu yllätyksiä...

...keskeistä on myös reaktioiden viivyttäminen. . Viime kädessä on kysymys pysyvämmän yhteisen ongelmanratkaisukyvyn kehittämisestä 
tuman kulkua elävänä, sijoittamaan jopa itsensä paikalle ja vertaamaan omia vastaavantyyppisiä kokemuksiaan sitä vasten - ja miettimään olisiko tällaisella menetelmällä käyttöä hänen omissakäytännöissään.

Olemme nyt kuulleet tarinan, katsokaamme tarkemmin, eräänlaisena diskurssianalyysin runkona, millaisia teemoja, rakenteita ja menetelmiä päivään sisältyy. Tämä esille saamiseksi olen kuviossa 1 purkanut päivän "osiin".

Tiivistän lähempää tarkastelua varten dialogipäivän viiteen ulottuvuuteen:

1) Ratkotaan kompleksista asiaa

2) ...tuomalla monitoimijainen kokoonpano

3) ...tilaanjossa dialogisuutta edistetään

4) ...fasilisoinnilla ja dialogisella menetelmällä (tulevaisuusdialogi)

5) ...tähtäimessä pysyvämpiongelmanratkaisukyky kompleksisessa asiassa

\section{Ratkotaan kompleksista, moni- ulotteista, epävarmuutta sisältävää, muuttuvaa asia...}

Tulevaisuusdialogi on tarjolla ratkomaan kompleksisia, monimutkaisia ongelmia. Mikä on kompleksista, on suhteellista, eikä siitä ole mitään yhtä määritelmää. Käsite tulee systeemi- ja kaaosteorioista ja yhteiskuntatieteissä se on lähinnä heuristinen käsite, jolla yritetään tavoittaa uusia näkökulmia inmisten toimintaan, organisaatioihin ja yhteiskuntaan. Kompleksiteetin käsitteellä yritetään tavoittaa asioiden, organisaatioiden ja verkostojen monimutkaista keskinäisriippuvuutta, ei-lineaarista muutosta, ajoittaista kaoottisuutta, yllättävyyttä, uuden kehkeytymistä (Tsoukas 2005, Stacey 2003, Shaw2001).

Tampereen tulevaisuusdialogin aiheena oli työllisyyttä koskevan yhteistyön edistäminen Tampereen seudulla. Työllisyyden edistäminen on viime kädessä hyvin moniulotteinen, kompleksinen ja rajoiltaan epämääräinen teema. Työllisyyteen vaikuttaa periaatteessa loputon joukko tekijöitä, jotka ovat kietoutuneet yhteen. Kaiken lisäksi työllisyystilanne on Suomessa ja Euroopassa viimeisen 20 vuoden aikana muuttunut hyvin yllättävästi, eikä ole mitään syytä olettaa, että yllätyksellisyys ja epävarmuus olisi vähenemässä. Viimeisimmät suuret yllätykset olivat lama ja siitä toipuminen ja hyppäys "tietoyhteiskuntaan". Seuraava yllätys on todennäköisesti mu- himassa Suomessa odotettavissa olevassa suuressa sukupolvenvaihdoksessa.

"Toisessa modernissa", tai millä käsitteellä käynnissä olevaan murroskautta haluammekin nimittää (Beck 2000), on tullut tavanomaiseksi korostaa yhteiskunnan, "toimintaympäristön", monimutkaisuuden, kompleksisuuden, fragmentoitumisen ja tähän liittyvän epävarmuuden ja ennustamattomuuden, jopa kaoottisuuden lisääntymistä (Tsoukas 2005). Tätä kaoottisuutta ei ole omiaan ollut vähentämään kehittämistoiminnan "projektoituminen" aina projektien ylitarjontaan ja "projektikaaokseen" asti (Arnkil. et. al. 2000).

Eräänlaiseksi vedenjakajaksi kehittämiskonsepteissa onkin muodostunut suhtautuminen monimutkaisuuteen, epävarmuuteen ja jatkuvaan muutokseen. Perinteisessä johtamis- ja kehittämiskonseptissa pyritään selkeyteen, pysyvyyteen, yksinkertaistamiseen ja epävarmuuden poistamiseen (Stacey 2003). Epävarmuus ja muutos on kuin ei-toivottu ja tungetteleva muukalainen, joka halutaan karkottaa. Aivan kuin nykyisin työpaikoilta, projektiväsymyksen vuoksi, projektit.

Monimutkaisuuteen ja epävarmuuteen vastaanottavaisemmin suhtautuvat konseptit puolestaan etsivät keinoja, joilla tällaisissa olosuhteissa saavutettaisiin parempi toimintakyky. Maailma ei ole muuttumassa vähemmän monimutkaiseksi ja epävarmemmaksi. Projektit eivät tule katoamaan. Muukalaista ei tule karkottaa, vaan suhtautua häneen kuin tuntemattomaan vieraaseen, jonka tapoihin pitää tutustua paremmin, jotta häntä ymmärtäisi.

Monimutkaisuuden edessä on itse "monimutkaistuttava" (Tsoukas 2005). Se tarkoittaa omien näkemysten rikastamista, mutta ennen kaikkea se tarkoittaa tiimien, organisaatioiden, verkostojen rikastamista, moninäkökulmaisuutta ja monimutkaisuuden kanssa tekemisissä olevien toimijoiden yhteistyön ja toimintavaihtoehtojen rikastamista.

\section{... tuomalla monitoimijainen \\ kokoonpano}

Tulevaisuusdialogi on tarjolla liittämään kompleksisten asioiden kanssa tekemisissä olevien useiden toimijoiden toiminnan paremmin yhteen, mukaan lukien projektit, joita nykyisin syntyy ja kuolee tiheään tahtiin.

Edellä jo todettiin, että monimutkaisuuden ja epämääräisyyden edessä on paikallaan "moni- 
mutkaistaa" itsensä, rikastaa asiaa ratkaisevaa subjektia, toimijaa, jotta toimintavaihtoehdot rikastuisivat.

Dialogin valmistelussa tunnistetaan käsiteltävän aiheen kannalta - tässä tapauksessa työllisyyden edistämisen kannalta - kiinnostavat ja tärkeät näkökulmat, toimijat, "äänet" ja heitä kutsutaan paikalle. Kuinka suuri joukko paikalle kutsutaan, riippuu tietysti aiheesta ja mahdollisuuksista. Tulevaisuusdialogin rakenne ja toteutustapa mahdollistaa kuitenkin suurenkin joukon läsnäolon. Tampereen tapauksessa paikalla oli noin sata henkeä, mutta periaatteessa heitä olisi voinut olla vaikka kaksinkertainenkin määrä.

Tampereen esimerkissä dialogisen tapahtuman osanottajina oli julkisten palvelujen edustajia (työvoimahallinto, Tampereen kaupunki, Tampereen seutu), yksityisiä yrityksiä, yrittäjäjärjestöjen edustajia, kolmannen sektorin (vapaaehtoistyön) edustajia, työllisyyden ja syrjäytymisen ehkäisyyn liittyvien projektien edustajia ja näissä projekteissa olevia työttömiä ja valtion työllisyysohjelman edustajia. Paikalla oli siis myös niitä, jota asia tärkeällä tavalla koskee, työttömiä, ei tosin paljon, mutta kuitenkin. Tämä on tärkeä näkökohta, sillä kansalaisten ja asiakkaiden läsnäolo dialogisissa tapahtumissa, olivatpa ne yksilöllisen asiakastyön puitteissa tai isommissa tapahtumissa, antaa tapahtumalle ulottuvuutta ja muuttaa sen sävyä ja luonnetta kuuntelevampaan ja tasa-arvoisempaan suuntaan.

Paikalla oli myös projektien edustajia. Itse asiassa koko dialogisen tapahtuman (ja koko vuosien 2002-2004) dialogisarjan koollekutsuja oli projekti, Euroopan Unionin rahoittama ESR projekti (Equal ohjelmasta), nimeltään Työn Tiet (Koivula 2004). Sen rooliksi oli muodostunut vähitellen - ja yllättävästikin - olla "projektien projekti", eli sitä käytettiin koostamaan Tampereen seudun työllisyyteen liittyviä projekteja ja ponnistuksia paremmin ja strategisesti yhteen. Työn Tiet siis tarjosi "tilan" koostaa muuten usein niin hajallaan olevaa projektimaailmaa. Nykyisin suosittu ratkaisutapa kehittää on perustaa projekti. Vielä parikymmentä vuotta sitten projekteista oli ehkäpä alitarjontaa, mutta tänä päivänä ylitarjontaa, aina projektikaaokseen asti. Tässä kehityksessä on paljon paradoksaalista. Eräs tärkeimmistä pulmista on, että tilapäisen ja ajallisesti rajatun projektimaailman ja pysyvämmän, jatkuvuutta edustavan "emotoiminnan" (kuten julkinen palvelu tai yritys) ei synny riittävää yh- teyttä. Projekteissa syntyvät "hyvät käytännöt" eivät siirry emotoimintoihin. Projektien ylitarjonnan vuoksi hankkeet eivät tunne toisiaan, eivätkä johtajat ja päätöksentekijät tunne projekteja "oikeasti", sillä raportit, jos niitä koskaan luetaan, ovat useimmiten vain kalpea aavistus siitä, mikä hankkeessa kenties oli mielenkiintoista ja pysyvämmin juurruttamisen arvoista.

Dialogiset foorumit tarjoavat mahdollisuuden koostaa tällaisia pyrkimyksiä.

Tavallaan voi siis ajatella, että tapahtuman kokoonpano pienoiskoossa edusti aiheen yhteiskunnallista kompleksisuutta ja hyvällä syyllä voi olettaa, että kokoonpano tarjosi hyvät mahdollisuudet yhdessä, tilapäistä projektimaailmaa myöten, tutkia Tampereen seudun työllisyyden edistämiseen liittyvät yhteistyön teemat monipuolisesti. Se subjekti, jonka asia pitäisi ratkaista, oli siis tavallaan läsnä. Se ei voinut, niin sanoakseni, delegoida asiaa jollekin muulle. Tämä monimutkainen (potentiaalinen) subjekti oli siis tutustumassa itseensä - "kuka minä olen" - ja mitkä ovat minun mahdollisuuteni tässä asiassa? On potentiaalisesti syntymässä uusi toimintayhteisö (Wenger 2002, 1998).

\section{..."tilaan"}

Dialogit järjestetään aina jossain tilassa. Tietämyksenhallintaa ja oppivaa organisaatiota koskevassa keskustelussa korostetaan, että hyvä dialogi ja hyvä oppiminen edellyttää hyvää "tilaa". Tämä "tilan" käsite on kuitenkin hyvin monipuolinen. Siihen kuuluu niin fyysinen, henkinen, emotionaalinen kuin ajallinenkin tila. Nonaka (Takeuchi ja Nonaka 2004 ) käyttää tästä japanilaista käsitettä "ba", jolla hän tarkoittaa henkilöiden astumista tietyksi ajaksi "merkitysten virtaan". Näissä tiloissa erityisen tärkeää on hiljaisen tiedon ja ilmitiedon yhteys, yksinkertaistetusti sanottuna ei-verbaalisen kokemustiedon ja käsitteellisen tiedon yhteyksien luominen. Tilassa kohdataan kasvokkain ja tätä kasvokkain kohtaamista ja kommunikointia on, tavallaan paradoksaalisesti, itse asiassa alettu korostaa tänä digitalisoitumisen ja kaukoviestinnän aikana. Tekniikalla voi tukea hyvää "tilaa", mutta ihmisten kohtaamista ei voi korvata. Välilliset viestimet tavallaan "haalentavat" todellisuutta ja ihmisten välisestä viestinnästä ohenee oleellisesti myös eiverbaalinen ulottuvuus, joka heikentää mahdollisuuksia aistia kommunikaation aitoutta. Luot- 
tamuksen kasvu on, kuten on todettu, kuitenkin dialogisuuden olennainen edellytys.

Tulevaisuusdialogit on tyypillisesti järjestetty suurryhminä, joissa on ollut 10 - 100 tai enemmänkin inmisiä paikalla. Tällaiset tilaisuudet kuten tietysti pienryhmätilanteetkin - ovat herkkiä myös tilan fyysisille järjestelyille. Dialogisuuden edistämiseksi suositellaan (Bohm, Isaacs, idid.) asettumista lähinnä ympyrämuotoon tai vastaaviin, joissa kasvokkaisuus ja tasa-arvoisuus korostuvat. Palataan siis tavallaan kreikkalaiseen teatteriin tai agoroille. Usein tilat on kuitenkin suunniteltu enemmänkin monologisuuden kuin dialogisuuden lähtökohdista.

\section{...ja dialogisilla menetelmillä (tulevaisuusdialogi)}

\section{"Kolminkertainen nykyhetki"}

Tulevaisuusdialogi on siis tarjolla monimutkaisessa tilanteessa monimutkaiselle kokoonpanolle tutustua toisiinsa (potentiaalinen subjekti) ja keskinäisiin käsityksiin toimintavaihtoehdoista. Tässäja nyt.

Tällaiset tapahtumat sijoittuvat aina johonkin kehityskulkuun. Ongelmia on useimmiten yritetty ratkaista ennenkin. Tampereen seudulla on tunnistettavissa noin kymmenen vuoden tietoisempi kehityskulku paremman työllisyyttä koskevan yhteistyön, "kumppanuuden", kehittämisessä. Aikaisemmat ratkaisut, niin hyvässä kuin pahassakin, välittyvät kuitenkin usein huonosti eteenpäin. Mennen ja nykyhetken välissä on usein katkos. Menneen ja nykyisen väliin tarvittaisiin siis jokin "tila". Myös nykyhetkessä on olennaisia katkoksia monitoimijaisuuden, fragmentaarisuuden, projektikaaoksen vuoksi. Tarvittaisiin siis tilaa tämän ylittämiseen. Myös tulevaisuuden suhteen on katkos: Se on monimutkainen, epävarma, monelta osin täysin ennustamaton. Tarvittaisiin jotain, jollla kuitenkin suhtautua siihen aktiivisesti. Tutustua muukalaiseen eikä karkottaa hänet.

Tulevaisuusdialogi on tilanne, jossa on läsnä menneisyyden nykyisyys (muistaminen), nykyhetken nykyisyys (huomion kiinnittäminen, huomiointi, havaitseminen) ja tulevaisuuden nykyisyys (odotus, ennakointi), eli "kolminkertainen nykyhetki", kuten Ricoeur (1984) asiaa nimittää, Augustinuksen distensio anami-käsitettä seuraten.
Tulevaisuusdialogityöskentelyllä halutaan paikalle loihtia tämä "kolminkertainen nykyhetki" ja tutkia sitä yhdessä. Rikkoa perinteinen lineaarinen aikakäsitys ja liikkua vapaammin. Tutustua itse kunkin "merkitykselliseen aikaan", koska kaikilla on omanlaisensa aika. Esimerkiksi tyypillisesti yksityisen yrityksen edustajan aika on nopeampaa, kiihkeämpää, kuin vaikkapa valtion virkamiehen aika, tai työttömän aika. Projekti-ihmisen aika on erilaista kuin emotoiminnassa olevien aika.

$\mathrm{Ne}$, joiden tulisi myötävaikuttaa asiaan, ovat siis tulevaisuusdialogissa, tässä tapauksessa, periaatteessa läsnä, juuri nyt. Tämä asian ja toimijoiden läsnäolo, "reaaliaikaisuus, "kolminkertainen nykyhetki", onkin tällaisten dialogitapahtumien oleellinen piirre.

\section{Käytännön toteutus}

Dialogisessa työskentelyssä käytetään usein ulkopuolista vetäjää. Niin tässäkin tapauksessa. Toimin tilaisuuden vetäjänä, yhdessä kollegojeni kanssa. Tämä siksi, että halutaan huolehtia dialogisten tilanteiden tärkeistä ominaisuuksista, joihin kuuluu moninäkökulmaisuuden, kuuntelun ja tasa-arvoisuuden edistäminen. Ulkopuolisen vetäjän työskentely tuo tilanteeseen neutraalin, jäsentävän, rauhoittavan ja viivyttävän elementin, joka on tärkeää monimutkaisten ja epämääräisten tehtävien sekä monitoimijaisuuden edessä.

Olemme suosineet kahden vetäjän käyttöä, mikäli mahdollista, toisen keskittyessä vetämiseen, toisen havaintojen tekemiseen dialogisuuden kehityksestä ja "ykkösvetäjän" auttamiseen roolissaan pysymisessä.

Tapahtuma organisoidaan "äänien kuulemisen" ympärille. Käsiteltävän aiheen kannalta tässä tapauksessa työllisyyden edistäminen - tunnistettiin siis kiinnostavat ja tärkeät näkökulmat, toimijat, "äänet".

Kutakin ääntä edustamaan valitaan ryhmä (37 henkeä) ja vetäjä haastattelee vuorollaan kutakin ääntä (äänen edustajia yksitellen), muiden kuunnellessa. Puhuminen ja kuunteleminen siis erotetaan toisistaan ja tällä halutaan edistää läsnä olevien sisäistä dialogia, jota he mielessään käyvät keskittyessään kuuntelemiseen (eivätkä esimerkiksi kommentin tai eriävän mielipiteen muotoiluun). Kuunteleminen onkin dialogisuuden olennainen elementti. Ääntä autetaan tule- 
maan esiin, tulemaan kuulluksi, artikuloitumaan. Vetäjän tehtävänä on huolehtia, että kukin ääni saa saman verran aikaa käyttöön, jotta moniäänisyys toteutuu tasapuolisesti.

Vetäjä toteaa, että "ihmeenomaisesti" siirrymme yhtäkkiä tulevaisuuteen, nyt ei olekaan marraskuun 28 päivä vuonna 2002, vaan marraskuun 28 päivä vuonna 2004. "Työllisyyttä koskeva yhteistyö on - "lehtitietojenkin mukaan" - edennyt Tampereen seudulla suotuisasti..." Tämän jälkeen vetäjä kysyy äänen edustajilta kolme kysymystä:

- Asiat ovat kannaltasi edenneet myönteisesti. Mistä sinä olet omalta kannaltasi erityisen ilahtunut?

- Mitä itse teit myönteisen kehityksen aikaansaamiseksi ja ketkä olivat tärkeimmät yhteistyökumppanisi tässä?

- Olitko huolissasi kaksi vuotta sitten jostain tähän asiaan liittyvästä ja mikä sai huolesi vähenemään?

Vetäjän tehtävänä on ainoastaankysyä. Hän tekee vain pieniä täydentäviä kysymyksiä edellä oleviin, pyrkien saamaan vastaajalta mahdollisimman konkreettisen kuvan siitä, mitä hän ja hänen yhteistyökumppaninsa ovat tehneet. "Milloin tämä tapahtui?" "Voitko kertoa vähän tarkemmin?".

Kunkin "äänen", eli pienen ryhmän kuuleminen kestää keskimäärin noin tunnin. Yhdessä päivässä voi siis "avata" maksimissaan noin 5-6 ääntä.

Vetäjä siis kysyy, äänet vastaavat, muut kuuntelevat. Mitä dialogista tässä on? Sehän on kysymys-vastaus -rakenne, tavallaan siis sarja monologeja. Dialogisuus tapahtuukin pääasiassa inmisten päässä, sisäisenä dialogina. He käyvät mielessään keskustelua päivän aikana esille tulleiden puhujien kanssa. Vetäjä pyytää "muistelemaan tulevaisuutta", jolloin äänet tulevat kertoneeksi pienoistarinoita. Tarinoiden kertominen onkin ihmisille luontainen tapa välittää kokemuksiaan ja se on luonteva tapa puhua omalla äänellään. Myös tämä tasa-arvoistaa dialogia. Mutta ennen kaikkea se tuo tapahtumaan elävän ja auki olevan elementin, johon voi itse eläytyä, vertailla sitä omiin kokemuksiin ja täydentää sitä mielessään. Tarina, erityisesti kuultuna, resonoi ja on tehokas tapa käsitellä monimutkaisuutta (Denning 2001, Weick 1995)). Välillä keskustelu avautuu saliin ja äänten keskinäiseen ajatusten- vaihtoon, jolloin myös tällaiset dialogiset elementit tulevat mukaan. Dialogisuus toteutuu siis tapahtuman kokonaisrakenteessa ja työskentelytavassa.

\section{Hyvä tulevaisuus}

Kysymyksistä on nähtävissä, että ne luotaavat seuraavia asioita: Ääni tulee kertoneeksi, mikä on hänelle merkityksellistä ("ilahduttaa"), mitä hän on valmis tekemään itse ("minä tein", sen sijaan, että puhuu passiivissa), ketä hän pitää tärkeinä kumppaneinaan (eli kertoo omista merkityksellisistä verkostoistaan). Ensin siis kysytään positiivisesta perspektiivistä. Asia on jollain tavalla ratkennut tai ainakin edennyt. Tällä raivataan tilaa positiiviselle ilmapiirille ja ratkaisuja hakevalle yhteistyölle. Tällaisessa ilmapiirissä on helpompi sietää myös vaikeiden kysymysten eteen tulemista. Läsnä olevat henkilöt siis kertovat toisilleen, mikä itse kunkin kannalta olisi toteutuessaan heille merkityksellistä. Tässä kohdin tulevaisuusdialogi ammentaa ennen kaikkea ratkaisukeskeisestä ajattelusta, jota on paljon käytetty esimerkiksi perheterapiassa (Seikkulaja Arnkil 2005).

Optimismi on siis tärkeä ulottuvuus. Mutta vetäjä kysyy myös mahdollisista huolista, jotta äänellä on mahdollisuus kertoa myös esteistä ja epäröinnistä. Esteistä ei kuitenkaan aloiteta, ettei keskustelu suistu depressiiviselle, väittelevälle, selittävälle ja puolustelevalle radalle. Ääntä pyydetään myös neuvomaan, miten huolenaiheet olisivat vältettävissä ("mikä sai huolesi vähenemään?").

Tällä tavoin jatketaan, ääni vuorollaan, "yleisön" kuunnellessa. Välillä vetäjä avaa puheenvuoron yleisölle, edelleen tulevaisuudessa pysyen, antaen mahdollisuuden "muistaa" vielä muista asioita, kuin mitä edessä haastateltu "ääni" on kertonut. Usein joitakin esille tulleita ideoita ja kehityskulkuja kehitellään eteenpäin, lisäillään, täydennetään.

Usein käytetään myös muista työskentelytapoja lomassa. Vetäjä esimerkiksi kehottaa mukanaolevia keskustelemaan välillä vieruskaverinsa kanssa, muistaako hän jotain kiinnostavia tapahtumia, tai onko hänellä erityisiä huolenaiheita.

Ihmiset ovat usein yllättyneitä ja huvittuneita tulevaisuusdialogista. Dialogisuuden käynnistyttyä huumorin ja leikinomaisuuden sävyttämä ilmapiiri edesauttaa luovuutta ja yhteistyöhenkeä. 
Huumori on keino käsitellä ja sietää monimutkaisuutta, ristiriitoja ja paradokseja, joita välttämättä tämäntyyppisissä aiheissa ja työskentelytavoissa esiintyy.

Dialogisiin tilanteisiin kuuluvat myös yllätykset. Tässä tapauksessa työttömän haastava kommentti, sitä seuraava "katkos" ja sitä seuraava yllättävä asian ratkeaminen aitoon työtarjoukseen, siinä ja nyt. Siinä jos missä oli läsnä kolminkertainen nykyhetki, ihan ilmielävänä!

Dialogeista tehdään aina muistiinpanot, jotka annetaan kaikille läsnä oleville. Dialogisten foorumien muistiinpanot laitettiin Tampereen tapauksessa myös verkkoon kaikkien tutustuttavaksi. On kuitenkin eri asia elää mukana dialogisessa tilanteessa, kuin lukea siitä

\section{...tähtäimessä pysyvämpi ongelman- ratkaisukyky kompleksisessa asiassa}

Olen tässä kuvannut tulevaisuusdialogin kerrallisena tapahtumana. Kuvaamani tulevaisuusdialogi oli kuitenkin ensimmäinen sarjassa dialogeja, joista seuraavat järjestettiin vuoden välien. Tässä kuvattu vuonna 2002 marraskuussa ja seuraavat marraskuussa 2003 ja 2004 . Kokoonpanoissa oli samoja ja erihenkilöitä, mutta samoja "ääniä". Koko prosessi tähtäsi Tampereen seudun työllisyyttä edistävän strategian vahvistamiseen ja oli siten osa strategian tuottamisen ja ennen kaikkea jalkauttamisen prosessia. Ensimmäisessä dialogissa tehtiin "aikamatka" vuoteen 2004, kuvittelemalla ja kertomalla eri perspektiiveistä, mitä positiivista asiassa on tapahtunut siihen mennessä. Vuonna 2004 näitä näkemyksiä tarkasteltiin - olihan niistä olemassa muistiinpanot ja arvioitiin missä määrin hyvä tulevaisuus oli todellisuudessa realisoitunut, oliko yllätyksiä ja oliko tapahtunut jotain muuta mielenkiintoista, jota 2002 ei osattu ennakoida. Sitten tehtiin taas aikahyppy eteenpäin. Vuonna 2003, "välissä", tarkasteltiin asioita niin ikään taaksepäin ja eteenpäin. Kuvattu tulevaisuusdialogi sijoittui siis isoon aikajatkumoon, jossa oli läsnä "iso kolminkertainen nykyhetki”. Näiden kokemusten ja työskentelytapojen tarkempi erittely ei kuitenkaan ole tämän artikkelin puitteissa mahdollista.

Kaiken kaikkiaan koko prosessilla tavoiteltiin sitä, mitä Gustavsen (2003) tarkoittaa yhteiskunnallisella liikkeellä, jolla tavoitellaan kehittämistoiminnan "kriittistä massa". Hän korostaa sitä että ei riitä, että kehitetään projekteissa irrallise- na ja irrallaan, vaan haasteena on leipoa kehittämistoiminta isompaan verkostoon, saada siitä voimaa ja vauhtia. Tarvitaan kestävyyttä. Muutoin uusinnetaan sitä, mikä alun perin oli ongelma, fragmentaarisuus ja katkokset - ajalliset ja yhteistyön katkokset. Gustavsenin analysoimissa Norjan työelämän kehittämisohjelmissa kestävyydenkantajiksi on pyritty rakentamaan pysyvämpiä alueellisia yhteistyömuotoja tutkimuksen, yksityisen sektorin ja julkisen sektorin välille.

Dialogiset foorumit ovat siis tarjokkaina joksikin pysyvämmäksi, kenties eräänlaiseksi monitoimijaiseksi kohtaamispaikaksi, "agoraksi", kuten Nowotny (2001) nimittää tutkimuksen, kehittämisen ja käytännön työn ja kansalaisten kohtaamisfoorumeita. Ei välttämättä sellaisenaan, eikä varsinkaan muodon vuoksi. Mutta kaikki dialogiset tapahtumat, olivatpa ne tiimin sisäisiä, tiimien välisiä, organisaation sisäisiä tai organisaatioiden välisiä, herättävät ideoita uusista yhteistyön ja kohtaamisen mahdollisuuksista ja toteutustavoista. Ne ovat "tarjoumia" (Gibson 1986) uudenlaisen toiminnan subjektin syntymiselle, joka voi joissakin tapauksissa saada myös pysyvämpiä institutionaalisia muotoja, kuten vaikkapa uusi yhteistoiminnallinen palveluyksikkö (Arnkil et. al. 2004)

\section{Tulevaisuusdialogin tulevaisuus}

Tulevaisuusdialogi on erilainen tapahtuma eri toimijoille. Meille tutkijoina se on ollut (yksi) toimintatutkimuksellinen tiedonhankintamenetelmä. Arvioitsijana se on ollut osallistuvan arvioinnin tiedonhankintaa. Tapahtumaan osallistuville käytännön työntekijöille se on ollut paitsi tiedonhankintaa, myös käytännön verkottumista ja yhteisten toimintamahdollisuuksien etsintää. Usein paikalla olleille kansalaisille se on niin ikään paitsi tiedon saamista, myös mahdollisuus kytkeytyä johonkin merkitykselliseen.

Teoreettisesti ja käytännöllisesti tulevaisuusdialogi sijoittuu useiden lähestymistapojen "voimakenttään" ja on omassa ja kollegojeni työssä ammentanut useista lähteistä. Sen teoreettinen tulkitseminen on kuitenkin vielä kovin keskeneräistä.

Eräs suurimmista yllätyksistä kolmikymmenvuotisella työurallani, jossa olen toiminut sekä asiakastyössä (ammatinvalintapsykologina), tutkijana, arvioitsijana että konsulttina, on ollut dia- 
logisten menetelmien ja siihen liittyvän verkostoitumisen suuri kysyntä erityisesti viimeisen kymmenen vuoden aikana. Tai tarkemmin sanoen yllätyksen on tuottanut dialogisten ja verkostoivien työskentelytapojen hyvä vastaanotto. Yllättävää on ollut, miten hyvin ja kiinnostavalla tavalla dialogiset tilanteet ovat "kantaneet itseään", ylittäen usein omat kokeilut, suunnitelmat ja teoreettiset käsitteet. Tilanteissa tapahtuu paljon - paljon enemmän kuin niistä ehtii havaitsemaan ja käsitteellistämään-ja ne ovat tarjonneet mielenkiintoisen näköalapaikan moniin tämän päivän ilmiöihin työelämässä ja yhteiskunnassa muutoinkin.

Tilanne muistuttaa siis jossain määrin anekdoottia maalaisisännästä maatalousnäyttelyssä:

Juureva isäntä katselee maatalousnäyttelyssä miten uusi, hieno traktori kyntää upeaa vakoa. Konsultti tulee isännän luo ja kysyy innoissaan: "Mitäs isäntä tuumaa?" Isäntä hieroo leukaansa ja sanoo: "Hyvin näyttää toimivan käytännössä... vaan toimiiko teoriassa?".

Työelämän kehittämisessä mikrotasolla, asiakastyössä, dialogisia menetelmiä on kehitetty erityisesti systeemisen ja ratkaisukeskeisen terapian ja perheterapian eri lähestymistapojen pohjalta (Andersen 1987, Andersson ja Goolishan 1992, Arnkil et. al., 2000 Seikkula et. al. 2005). Erityisen keskeistä näissä on asiakkaan ja asiantuntijan suhteiden muutos asiakkaan ja arkikielen "eduksi" ja asiakkaiden "luomuverkostojen" tuleminen mukaan ratkaisuresurssiksi aikaisempaa painokkaammin. Esimerkiksi tulevaisuusdialogissa esiintyvä moniäänisyys ja ratkaisukeskeisyys ammentaa siten pitkälti täältä. Yhteenveto dialogisista menetelmistä löytyy Stakesin verkostotiimin internetistä: http://www.stakes.fi/hyvinvointi/verk/menetelmat/index.htm

Samantapainen teoreettis-käytännöllinen kehitys on ollut käynnissä myös makrotasolla työelämän kehittämisessä. Kuuluisin esimerkki on demokraattinen dialogi, jota on kehittänyt erityisesti Gustavsen $(2003,2002,1996)$ kollegoineen. Demokraattinen dialogi perustuu pitkälti Habermasin kommunikatiivisen toiminnan teoriaan (Habermas 1984), jossa ydinkysymyksenä on otollisen "tilan" luominen kommunikaatiolle. Demokraattista dialogia on sovellettu jopa koko maan laajuisissa työelämän kehittämisohjelmissa (kuten Norjassa ja Ruotsissa), joissa on ollut tuhansia projekteja. Tavoitteena on ollut uudenlaisen kehittämisen infrastruktuurin luominen työelämään, jossa eri tahot, tutkijat, asiantuntijat, käytännön työelämässä toimivat kohtaavat tasavertaisesti, niin että kaikkien "ääni" kuuluu ja tulee kuulluksi. Tulevaisuusdialogi on siten eräänlainen muunnelma demokraattisesta dialogista.

Sama kehitys on vahvistunut tietoyhteiskuntakeskusteluissa ja teorioissa. Kuuluisin esimerkki on Nonakan (ibid.) teoria oppimisesta ja oppivasta organisaatiosta, jossa painotetaan erityisesti hiljaisen tiedon (tacit knowledge) merkitystä Polanyin (1974) alun perin esittämää käsitettä mukaillen.

Itse dialogisuuden käsitteeseen liittyy kuitenkin paljon ristivetoa ja epäselvyyttä, menetelmistä puhumattakaan. Burbules (1993)toteaa, että dialogisuus on pikemminkin jatkumo väittelystä kyselevään tutkimiseen ja saman tapahtuman puitteissa voidaan liikkua enemmän dialogisuuteen ja siitä poispäin ja takaisin. Myös dialogin tulos voi vaihdella yhteisymmärryksen saavuttamisesta eriasteiseen erimielisyyteen. Itse erimielisyydessä on monia asteita vaihdelleen paremmasta toisen ymmärtämisestä aina yhteen sovittamattomaan moninaisuuteen asti. Dialogisuuden vaiheista ja sitä edistävistä menetelmistä on niin ikään monia käsityksiä (Isaacs ibid., Schein 1993, Roman 2005).

Myös tulevaisuustyöskentelyä on monenlaista. Riippuen käsillä olevan aihepiirin "ennustamattomuuden asteesta" ja käsillä olevista toimintavaihtoehdoista. Jos ennustettavuus on suurempaa voi tulevaisuustyöskentely olla enemmän lineaarista ekstrapolointia (ennusteet), mutta jos se on matalampaa, tarvitaan skenaariotyyppistä työskentelyä ja varautumista yllättäviin sattumiin (Tsoukas, ibid., Cornish 2004). Tulevaisuusdialogi sijoittuu, tilanteesta riippuen, jonnekin näiden välimaastoon.

Varsinkin johtamiseen liittyy dialogisuuden suhteen paljon ambivalenssia. Johtamista hallitsee edelleenkin pikemminkin muukalaisen karkottamisen, kuin tuntemattomaan tutustumisen paradigma. Perustasolla ja projekteissa on voitu

\section{Lähteet}

Andersen, T. (1987). The Reflecting Team: Dialog and Meta Dialog in Clinical work. Family Process, 26, 415-481.

Anderson, H. \& Goolishian, H. (1992). The 
Client as the Expert: a Not Knowing Approach to Therapy. Teoksessa Therapy as a Social Construction (S. McNee \& K. Gergen toim.), pp. 25-39. London: Sage Publications.

Arnkil, R., Karjalainen, V., Aho, S., Lahti, T., Lyytinen S-M. ja Spangar, T. (2004). Yhteispalvelusta palvelukeskuskonseptin kehittämiseen. Työhallinnon julkaisu 339: 2004

Arnkil, R., Rissanen, , Pitkänen S., Piirainen, T., Koski, P., Berg, P. ja Vartiainen, M. (2003). The Finnish Workplace Development Programme-A Small Giant? Evaluation Report. Ministry of Labour, Finland.

Arnkil, R. ja Spangar, T. (2001). Incentive Mesures - Silta Suomen työhallinnon modernisointiin? Evaluoinnin loppuraportti. Työhallinnon julkaisu 298. 2001.

Arnkil, R ja Spangar, T. (2003). Emergent Evaluation and Learning in Multi-stakeholder Situations. Paper presented at the Fifth European Conference on Evaluation of the Structural Funds, Budapest 26-27 June.

Arnkil, T. , Eriksson, E. ja Arnkil, R. (2000). Palveluiden dialoginen kehittäminen kunnissa - Sektorikeskeisyydestä ja projektien kaaoksesta joustavaan verkostointiin. Stakes. Raportteja 253.

Bakhtin, M. (2002). The Dialogic Imagination. Austin: Texas University Press.

Bohm, D. (1996). On Dialogue. (ed. Nichol. L.) London: Routledge.

Borja, J. \& Castells, M. (1996). Local and global - management of cities in the information age. London: Earthscan.

Beck, U. (2000). Brave New World of Work. Polity Press.

Burbules, N. (1993). Dialogue in Teaching. Theory and Practice. Teacher College. Columbia University. New York.

Cornish, E. (2004). Futuring: The Exploration of the Future. World Future Society. Maryland.

Denning, S. (2001). Storytelling - How Storytelling lgnites Action in Knowledge-Era Organizations. Butterworth-Heinemann. Boston.

Denzin, N. ja Lincoln, Y. (2000) toim. Handbook of Qualitative Research. Sage Publications. Thousand Oaks.
Gibson, J. (1986) The Ecological Approach to Visual Perception. Lawrence Erlbaum Associates. Hillsdale. New Jersey.

Gustavsen B. (2003). Action research and the problem of the single case. Concepts and Transformation, vol. 8, no. 1 (2003), pp. 9399

Gustavsen, B. (2002). Constructing New Organisational Realities - The Role of Research. Concepts and Transformation, vol. 7 no. 3, pp. 237-261

Gustavsen, B., Hofmaier, B., Ekman Philips, M. ja Wikman, A. (1996). Concept-driven Development and the Organization of the process of Change - An evaluation of the Swedish Working Life Fund. John Benjamins. Amsterdam/Philadelphia.

Habermas, J. (1984). The Theory of Communicative Action. Polity press.

Heiskanen, T. ja Hearns, J. (2004). Information Society and the Workplace-Spaces, Boundaries and Agency. Routledge. London.

Isaacs, W. (1999). Dialogue - The Art of Thinking Together. Currency. New York.

Isaacs, W. ( 1996). The Process and Potential of Dialogue in Social Change. Educational Technology. January-February, 20-29.

Koivula, U-M. (2004). Oppiva verkosto työllisyydenhoidon palveluprosesseja jäljittämässä. Työpoliittinen aikakauskirja 2: 2004.

Nonaka, I. ja Nishiguchi, T. (2001). Knowledge Emergence. Oxford University Press.

Nowotny H, P Scott ja M Gibbons (2001). ReThinking Science - Knowledge and the Public in the Age of Uncertainity, Cambridge: Polity Press.

Polanyi, M. (1974). Personal Knowlegde-Towards a Post-Critical Philosophy. University of Chicago Press.

Ricoeur, P. (1984). Time and Narrative. University of Chicago press.

Roman, J. (2005). A Study of Organizational Dialogue. Väitöskirja. Tarkastettu 27.8. 2005. Helsingin teknillinen korkeakoulu.

Schein, E.(1993). On Dialogue, Culture, and Organizational Learning. Organizational Dynamics. Winter, pp. 40-41.

Seikkula, J. ja Arnkil, T. (2005). Dialoginen ver- 
kostotyö. Tammi.

Seikkula, J. ja Arnkil, T. (2005). Network Dialogues. Karnac Publishers. Kensington. UK.

Seikkula, J., Arnkil, T. ja Eriksson, E. (2003)

Postmodern Society and Social networks:

Open and Anticipation Dialogues in Network Meetings. Family process. Vol. 42 no.2.pp. 185-203.

Shotter, J. (1993). Conversational Realities: Constructing Life Through Language. London: Sage.

Spangar, T., Jokinen, E. \& Filander, K. (2004). AiHe-Enemmän kuin aihioita aikuisopiskelun henkilökohtaistamiseen. AiHe-projektin kokonaisarviointi 2003. Opetushallitus.

Spangar T. (1998). Reframing Career Counselling in Terms of Counsellor-client Negotiations. Dissertation. University of Joensuu Publications in Social Sciences N:o 34.

Stacey, R.D. (2003). Strategic Management and Organisational Dynamics. The Challenge of
Complexity. Prentice Hall.

Stacey, R.D. (2000). The Emergence of Knowledge in Organisations. Emergence 2(4) pp. $23-40$

Shaw, P. (2001). Changing Conversations in Organizations -A complexity Approach to Change. Routledge. London.

Takeuchi, H. ja Nonaka, I. (2004). Hitotsubashi on Knowledge Management. John Wiley and Sons.

Tsoukas, H. (2005). Complex Knowledge. Oxford University Press. New York.

Weick, K. (1995). Sensemaking in organizations. Sage, London.

Wenger, E. , McDermott, R. \& Snyder, W.M. (2002). Cultivating Communities of Practice. Harvard Business School Press.

Wenger, E. (1998). Communities of PracticeLearning, Meaning and Identity. Cambidge University Press. 